\title{
Reputation and Advertising of Collective Brand Members in the Wine Industry: The Moderating Role of Market Share
}

\author{
Ricardo Sellers-Rubio $^{a}{ }^{(D)}$, Francisco Mas-Ruiz ${ }^{b}$ (D) and Franco Sancho-Esper $^{c}$ (D)
}

\begin{abstract}
This paper analyzes the nonlinear relationship between the advertising investment and reputation of collective brand members in an experience goods industry, as well as the moderating role of their market share within the collective brand. The central assumption is that the quality reputation of collective brand members has a positive effect on their advertising investment until a reputation threshold is reached, after which the effect on advertising investment becomes negative. This change in the slope is explained by the information sets (firm reputation and collective reputation) used by consumers to reduce uncertainty, which leads to a weaker motivation for the firm to invest in advertising. In addition, scale economies of advertising mean that the market share of collective brand members negatively moderates the curvilinear relationship between quality reputation and advertising investment. The results for a sample of 176 companies in a Spanish experience goods industry (i.e., winemaking) between 2004 and 2014 show an inverted U-shaped relationship between the advertising investment and reputation of collective brand members. The results also show that market share negatively moderates this curvilinear relationship. (JEL Classifications: M31, M37, Q13)
\end{abstract}

Keywords: advertising, collective brand, company reputation, wine.

\section{Introduction}

The relationship between advertising investment and quality allows researchers to evaluate the role of advertising by using the idea that if widely advertised products

The authors gratefully acknowledge helpful comments and advice from an anonymous reviewer. The authors also extend their gratitude towards the editor.

${ }^{a}$ Department of Marketing, University of Alicante. Crta. San Vicente s/n. 03690, Alicante (Spain); e-mail: ricardo.sellers@ua.es (corresponding author).

${ }^{\mathrm{b}}$ Department of Marketing, University of Alicante. Crta. San Vicente s/n. 03690, Alicante (Spain); e-mail: francisco.mas@ua.es.

${ }^{\mathrm{c}}$ Department of Marketing, University of Alicante. Crta. San Vicente s/n. 03690, Alicante (Spain); e-mail: franco.sancho@ua.es.

(C) The Author(s), 2021. Published by Cambridge University Press on behalf of American Association of Wine Economists. This is an Open Access article, distributed under the terms of the Creative Commons Attribution licence (http://creativecommons.org/licenses/by/4.0/), which permits unrestricted re-use, distribution, and reproduction in any medium, provided the original work is properly cited. 
are of low quality, advertising can replace quality, but if widely advertised products are of high quality, advertising can promote better quality products (Tellis and Fornell, 1988). Our study is built on Klein and Leffler's (1981) idea that reputation is an indicator of quality in experience goods. As quality is difficult to assess before purchases are made in experience goods industries, the producer repeatedly delivers the promised quality to show that it is not exploiting its information advantage with respect to current quality (Fernández-Barcala and González-Díaz, 2006). Hence, the producer creates a reputation for its brand name that can be used as a guarantee for future consumers. Within this context of the quality-guarantee effect, the economic analysis of advertising (see Bagwell, 2007) draws on the model of Klein and Leffler (1981). According to this model, reputation and advertising investment are positively related because companies that produce high-quality products use advertising investment as company-specific capital to assure consumers that they have a lasting commitment to quality (Klein and Leffler, 1981; Archibald, Haulman, and Moody, 1983). Our research builds on this idea by analyzing the relationship between the advertising investment and the reputation of the members of a collective brand.

We focus on situations where the high- or low-reputation brand name of a company exists within a collective brand (or umbrella brand name), where quality is certified by an institutional system. A collective brand is a signal that distinguishes goods or services produced by firms belonging to an association, which is registered to guarantee the origin, nature, or quality of certain goods and services (Directive 89/ 104/CEE). For example, a protected designation of origin (PDO), such as the wines of the Rioja region, is a public collective brand used to describe foodstuffs that are produced, processed, and prepared in a given geographical area using recognized know-how (see Loureiro and McCluskey, 2000). Companies often cooperate with each other through such collective brands to promote high-quality products (Marette, 2005). These arrangements can have substantial managerial implications. At this point, our interest is in circumstances in which collective brand members make advertising investments to promote their own individual brands. We assume a nonlinear relationship between the quality reputation of collective brand members and advertising investment (see Figure 1). For members with a low reputation, the existence of a collective reputation would encourage a low advertising investment. Members with a moderate reputation would consider a higher advertising investment to be justified. Finally, companies with a reputation for high quality also benefit from a collective reputation as members of a collective brand, so the use of both sets of information (firm reputation and collective reputation) by consumers would lead these companies to have a weaker motivation to invest in advertising.

Advertising has also traditionally been linked to market structure (Sutton, 1991; Lee, 2002), yet this relationship is far from being fully understood. The conventional view is based on assumptions about oligopolistic mutual interdependence or the suitability of advertising. The relationship follows an inverted U-shape curve, which implies that moderately concentrated industries engage more intensively in advertising than atomistically competitive industries and highly concentrated industries. Our 
Figure 1

Reputation, Market Share, and Advertising Investment of Collective Brand Members

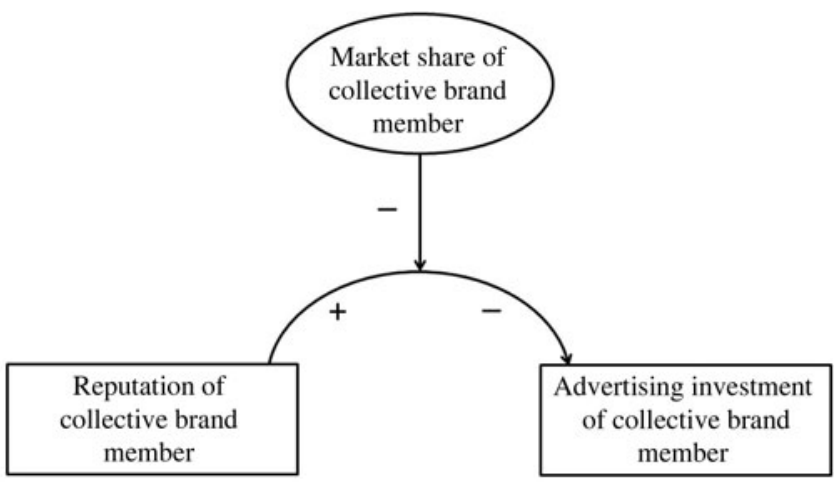

research extends this approach by considering whether the nonlinear relationship between firm reputation and advertising investment is moderated by the market structure of a collective brand, in terms of the market share of the company within its collective brand (see Figure 1). We assume that variance in market share within a collective brand determines the preferred differentiation device (i.e., collective brand or company brand; Benavente, 2013). Following Deluze and Lanotte's (2010) proposition, members with a low market share in their collective brand have fewer financial resources to develop their individual brand, and since they maintain minimum standards of quality, they can only benefit from collective reputation. However, members with high market share could benefit from both company reputation and collective reputation, as well as the scale economies implicit in the generic advertising investment of the collective brand. Thus, market share may be expected to negatively moderate the curvilinear relationship between reputation and advertising investment.

The objective of this study is to examine the nonlinear relationship between the advertising investment and reputation of collective brand members, as well as the moderating role of their market share in the collective brand. The analysis is carried out in the Spanish wine industry because of the large number of public collective brands (i.e., PDO labels) in this industry and the diversity of brand types (coexistence of individual and collective brands).

\section{Literature Review}

Theoretical research in economics has examined the relationship between quality and advertising investment from different perspectives. Comanor and Wilson (1979) surveyed early empirical research, which describes the circumstances under 
which low-quality producers advertise more, relying on the anti-competitive effects of advertising (i.e., misleading advertising; Tellis and Fornell, 1988). This idea is aligned with the conventional perspective posited in marketing that advertising is a means of differentiating a product and of sustaining high market shares and profits (Lilien, 1978). For example, Comanor and Wilson (1979) concluded that advertising could highlight preferences for specific brands - even when the physical characteristics are not different - so that companies with low-quality products could use advertising to compensate for the loss of quality. From this perspective, product quality and advertising investment would be negatively related.

Alternatively, the study by Bagwell (2007) examined the relationship between advertising and product quality by building on the model proposed by Nelson (1974), which focuses on experience goods whose quality cannot be determined prior to purchase. This author drew upon the information theory of advertising (Stigler, 1961) to argue that quality differences are inherent among competitive products but that consumers may not be fully informed about them. Companies could advertise to both inform and mislead consumers about these differences, but misleading advertising will probably not be productive as consumers cannot verify the quality of the product through inspection or use. Therefore, companies with high quality will make a greater advertising investment to inform consumers (Tellis and Fornell, 1988). If consumers respond to advertising, these companies will advertise more, and quality and advertising investment will be positively related.

However, empirical evidence is divided. Empirical studies have shown a positive relationship between quality and advertising investment (Marquardt and McGann, 1975) as well as inconclusive results (Farris and Buzzell, 1979). Other studies have revealed a positive association when quality ratings are published and widely disseminated (Archibald, Haulman, and Moody, 1983) or when there is an extensive market experience (Tellis and Fornell, 1988). Conversely, it has been shown that providers of low-quality services could advertise and prosper, which has been explained because deceiving consumers relies on "illusory qualities" (Parker, 1995). In addition, Horstmann and Moorthy (2003) observed a nonlinear relationship between quality and advertising investment, explained by the influence of the use of the productive capacity of services.

Other theoretical economic models describe the relationship between quality and advertising investment, focusing on reputation as an indicator of the quality of experience goods. From this perspective, advertising is studied in the context of the quality-guarantee effect (Bagwell, 2007). The role of company reputation has been addressed in the theoretical models of Klein and Leffler (1981) and Shapiro (1983), who explain the reputation of a company through its past output quality. Thus, for experience goods, product quality is imperfectly observable prior to purchase and can only be determined through its use. This implies that consumer demand will depend, at least in part, on consumer predictions regarding product quality. In fact, the quality reputation of companies is one of the most important factors used by consumers when making these predictions. Thus, this company 
reputation model considers that the reputation of a company mainly depends on previous quality output. In this context, the model of Klein and Leffler (1981) assumes that reputation and advertising investment are positively related because companies that produce high-quality products use company-specific capital, such as logos and advertising campaigns, to assure consumers that they have a lasting commitment to quality (Archibald, Haulman, and Moody, 1983). Furthermore, these advertising investments (i.e., brand name capital expenditures) would become sunk costs that are lost if the company breaks its promise of high quality. Our research extends this last idea, focusing on the nonlinear relationship between the reputation of member companies of a collective brand and advertising investment in an experience goods industry (see Figure 1).

Finally, an important perspective in the economic analysis of advertising focuses on the relationship between advertising and market structure (Sutton, 1991; Lee, 2002). From this perspective, game theory models can be used to predict how the endogeneity of sunk costs (advertising) and the "toughness of price competition" influence the relationship between market size and concentration (Bagwell, 2007). One of the conventional views is that rivalry in advertising is determined by the structure of the market, in terms of both leading companies' market power within an industry and the oligopolistic structure of the market with differentiated products (Willis and Rogers, 1998). In general, the market power of leading companies, in terms of their market share, predicts advertising intensity in the industry because overinvestment in advertising is less likely to occur in an oligopoly with a dominant company. Alternatively, advertising intensity increases with concentration, at least for some degrees of concentration, because an increase in concentration reduces the incentive of a leading company, which markets differentiated products, to compete on price, which inevitably creates greater reliance in advertising. We also extend this approach by arguing that market share within the collective brand plays a moderating role in the relationship between reputation and advertising investment (see Figure 1). We attach importance to the conditions that encourage advertising investment and a reputation for high quality for the company's brand within a collective brand.

\section{A. Quality Reputation and Advertising Investment: The Moderating Role of Market Share}

(1) Advertising Investment and Quality Reputation of Collective Brand Members

Collective brands are reputation mechanisms through which member companies share a collective reputation, and customers of any company can learn about the quality of all member companies. This idea is developed in the theoretical collective reputation model of Tirole (1996), which is rooted in the theory of reputation with asymmetric information on quality in the market (Landon and Smith, 1997). Collective reputation, which can be thought of as the aggregation of the individual reputations of members, uses group information to proxy the product quality of the 
individual company. In fact, in industries with many producers, specific information on the current or past quality of a given company is limited, and it is only possible (or would be cheaper) to obtain information on the quality of a group of companies with which the specific company can be identified. This group information can be used as an indicator of the product quality of a company in the group.

A collective brand constitutes a source of differentiation (e.g., PDO). In the case of experience goods, the purpose of the collective brand for its members is to mitigate market failures derived from information asymmetries. In the same way, the individual brand is another way of differentiating and signaling because a company can develop a product with superior quality and signal that through its own brand and firm-level traceability (Benavente, 2013). Although a priori it is not possible to rank the qualities implicit in the brand of the company and the collective brand, a company that has a strong or moderate brand within the collective brand necessarily has a higher reputation for quality than other companies in the same collective brand. Otherwise, the advertising investment in the company brand would not be justified. Thus, we assume that members of a collective brand with a moderate reputation advertise more.

On the other hand, members of a collective brand with both low and high reputations would be inclined to invest less in advertising. This is because the information sets assumed to be used by consumers in each model (firm reputation and collective reputation) may be too restrictive (Landon and Smith, 1997). The company reputation model of Klein and Leffler (1981) highlights company quality reputation as the most important information source for consumers when making predictions about the current quality of a product, where a company's reputation is explained through its past output quality. Conversely, the collective reputation model of Tirole (1996) assumes that consumers use group-level information to proxy the product quality of member companies. In fact, even when consumers have access to free- or low-cost information on current quality, collective reputation indicators can also affect the demand for some products, as some specific collective brand products could benefit from snob appeal or from an easy pronunciation of the name of the collective brand (Landon and Smith, 1997). Since consumers can easily observe collective brand reputation indicators, this information can influence consumer demand, and we assume that members of a collective brand with a low company reputation would be inclined to invest little in advertising.

For collective brand members with a high company reputation, both types of information used by consumers (company reputation and collective reputation) may influence advertising investment: collective brand members with a highquality company reputation (high past quality) also benefit from a collective reputation and might have a lower motivation to invest in advertising because the company reputation and the collective reputation would reduce the uncertainty for consumers surrounding the purchase and would encourage product trial with less investment in advertising. Thus, given consumers' use of a recognizable brand as a means of coping with perceived risk (Smith and Park, 1992), we consider that a high 
company reputation and collective reputation reduce the amount of additional information that consumers need to assess a product. This situation offers an opportunity for companies to reduce advertising investment with respect to the investment needed to foster the awareness and trust of consumers in situations of moderate company reputation.

In short, this argument suggests a positive association between the quality reputation of collective brand members and advertising investment up to a reputation threshold, at which point the relationship between reputation and advertising investment becomes negative. Consequently, we propose the following hypothesis:

H1. The relationship between the quality reputation of a collective brand member and its advertising investment is nonlinear, with a positive slope at lower levels of reputation and a negative slope at higher levels of reputation.

\section{(1) The Moderating Role of a Company's Market Share}

We build on several recent studies (e.g., Benavente, 2013) that consider that variance in market share within a collective brand determines the preferred differentiation device (collective brand and company brand) by firms. We extend these studies by analyzing the moderating role of market share in the nonlinear relationship between quality reputation and advertising investment of member companies of a collective brand (see Figure 1). Our argument is based on the idea stated by Farris and Buzzell (1979) and Lilien (1978) that market share could capture firm-specific cost-related effects. We expand this argument to the context of the competitive structure of members of a collective brand in the market.

From a collective brand perspective, according to Deluze and Lanotte (2010), members with a low market share in the collective brand have few financial resources to develop their own individual brands; moreover, since they have minimum quality standards, they can only benefit from collective reputation. Members with a high market share could benefit from both the company reputation and the collective reputation, as well as the scale economies implicit in the generic advertising investment of the collective brand. Collective brands tend to include generic advertising of an informative nature, whereas member companies might even engage in misleading advertising. Thus, the advertising investment of companies with high market share is lower when they launch a new individual brand due to the pre-existing stock of information and the collective brand guarantee, which acts as an "umbrella" reputation (Wernerfelt, 1988). This concept of scale economies has traditionally been used by researchers who analyze market share as a market factor that affects a firm's advertising investment (Farris and Buzzell, 1979). Under this approach, Lilien (1978) found that higher market shares are associated with lower advertising investments due to the scale economies in advertising activities. 
Therefore, it is expected that a company's market share within the collective brand moderates the curvilinear relationship between the company's reputation and advertising investment. Thus, companies with a high-quality reputation that also have a high market share within a collective brand would invest less in advertising than companies with a high-quality reputation that have a low market share. Consequently, we propose the following hypothesis:

H2. The market share of a company within its collective brand negatively moderates the curvilinear relationship between its advertising investment and its reputation.

\section{Method and Sample}

\section{A. Method}

Our empirical model is based on the simple Dorfman-Steiner condition (1954). According to this condition, a profit-maximizing monopolist will advertise more as the demand elasticity of advertising increases and price elasticity decreases. Applications of the Dorfman-Steiner model to the case of an imperfect competition show how strategic effects and market structure can also play a role (Tremblay and Tremblay, 2012). First, from the perspective of strategic effects, behavioral economics models indicate that advertising changes consumer beliefs about product quality because advertising creates a prestige effect. Thus, advertising increases perceived quality, and firms benefit from increased product differentiation. This outcome is consistent with some generic products, where the leading-national brand advertises heavily, and its generic counterparts do not advertise at all (aspirin and the leading company Bayer). This implication is also consistent with the outcome of Klein and Leffler's (1981) model, which has been applied to advertising in the context of the quality-guarantee effect (Bagwell, 2007). Thus, this model introduces advertising as an investment in brand name capital that is forfeited if one firm degrades its quality reputation. We extend this idea by considering that firm advertising is explained by the quality reputation of collective brand members. Second, the extension of the Dorfman-Steiner model implies a link between advertising and market power in such a way that an increase in market power (i.e., as the demand becomes more inelastic) leads to greater advertising (Tremblay and Tremblay, 2012). When the price elasticity of demand is infinite, as it is in perfectly competitive markets, firms have no incentive to advertise unless they belong to a collective brand. Thus, we extend this logic to explore the moderating role of a company's market share within the collective brand in the relationship between quality reputation and advertising investment.

In short, the general regression model in Equation (1) is a reduced form of the equation for an advertising model.

$$
A_{j t}=A\left(R_{j t-1}, X_{j t}\right)+\varepsilon_{A_{j t}}
$$


Where $A_{j t}$ is the advertising investment by company $j$ in period $t, R_{j t-1}$ is the quality reputation of company $j$ in period $t-1, X_{j t}$ is a set of control characteristics of company $j$ in period $t$, and $\varepsilon_{A_{j t}}$ is a zero mean random variable with variance $\sigma_{A}^{2}$. In this baseline model, advertising investment is considered a function of firm reputation. To estimate the proposed panel data model, we operationalize it in the following way. In the first specification, a firm's advertising investment is a linear function of the firm's reputation $R_{j t-1}$ and control variables $X_{j t}$, and is specified in the following way:

$$
A_{j t}=\beta_{0}+\beta_{1} R_{j t-1}+\beta_{2} X_{j t}+\varepsilon_{A_{j t}}
$$

In the second specification, firm advertising investment is a nonlinear function (a quadratic relationship) of the firm reputation as well as control variables and is specified in the following way:

$$
A_{j t}=\beta_{0}+\beta_{1} R_{j t-1}+\beta_{2} R_{j t-1}^{2}+\beta_{3} X_{j t}+\varepsilon_{A_{j t}}
$$

An extension of this model can be used to test whether a firm's market share in the collective brand $\left(M S_{j t}^{c}\right)$ can moderate the nonlinear effect of its reputation on advertising investment. Thus, the third specification includes a two-way interaction and is specified in the following way:

$$
\begin{aligned}
A_{j t}= & \beta_{0}+\beta_{1} R_{j t-1}+\beta_{2} R_{j t-1}^{2}+\beta_{3} M S_{j t}^{c}+\beta_{4} R_{j t-1} M S_{j t}^{c}+\beta_{5} R_{j t-1}^{2} M S_{j t}^{c} \\
& +\beta_{6} X_{j t}+\varepsilon_{A_{j t}}
\end{aligned}
$$

The estimation procedure is panel least squares with robust estimation for the variance/covariance matrix.

\section{B. Context and Sample}

This research uses data from the Spanish wine industry to test the hypotheses regarding the relationship between advertising and reputation. Spain is one of the leading wine producers in the world. With almost 1 million hectares of vineyards, Spain's average wine production between 2004 and 2014 was around 42.5 million hectoliters. This volume corresponded to around $15.6 \%$ of global wine production in 2014 . Around 4,500 wineries operate in Spain. These companies belong to two polarized groups: big companies and family-owned wineries. While firms in the former group tend to sell a low-price product for mass consumption, many firms in the latter group produce high-price, high-quality wines that are produced on a small scale. This pursuit of quality can be explained by the role of PDOs in this industry. PDOs protect the image and quality of products from specific geographical areas and enable small- and medium-sized wineries to develop marketing and promotional 
strategies for both domestic and international markets. Nowadays, around $40 \%$ of the wine is produced under 1 of the 90 wine PDOs in Spain. The Spanish wine market is also a highly concentrated market. According to Anderson and Pinilla (2020), the CR4 (the concentration ratio, calculated as the sum of the market share percentage held by the four largest companies in the industry) for 2014 was $20.1 \%$.

Despite its importance, the Spanish wine industry faces a major problem due to a steady decline in domestic wine consumption in recent years. The average consumption per capita was around 26 liters in 2004 and 19 liters in 2014, with a shift toward high-quality and more expensive wines that have maintained the value of the domestic market. However, the domestic market consumes barely one-third of overall production, and export growth and expansion to new markets were crucial to ensure the viability of the sector. Accordingly, there was $50 \%$ growth in wine exports between 2004 and 2014, accounting for 23.8 million hectoliters in 2014 and more than half of Spain's wine production. Furthermore, Spanish wine producers have made major changes to their marketing strategies, improving their branding efforts, paying great attention to their packaging strategies, and increasing their advertising investment.

The empirical analysis was performed using a sample of companies operating in the Spanish wine industry between 2004 and 2014. Given the scope of the paper, the sample was selected from the population of companies registered in the 1102 section of the CNAE-2009 classification, which is the equivalent of code 2084 of the U.S. SIC classification (wines, brandy, and brandy spirits). The initial data were taken from the Information for Advertising Expenditures (INFOADEX) database. The initial sample comprised 669 companies that had invested at least 1 euro in advertising during this period. To ensure the homogeneity of the sampled companies, we excluded wineries that primarily produce brandy and other spirits. So that we could test the hypotheses, we also required the company to be included in the Sabi database (the Iberian version of the Bureau Van Dijk database), to belong to a PDO, and to have wines that are included in the wine guide database. To estimate a firm's individual reputation, we required there to be at least two references to that firm in the wine guide. This procedure reduced the sample to 217 wineries. Finally, we only considered companies operating continually from 2004 to 2014 that had invested at least 1,000 euros in advertising in each and every year of the study period. The inclusion of lagged variables (e.g., reputation and market share) and variables in differences (e.g., collective brand market growth) required the use of balanced panel data. Accordingly, we excluded the companies that only invested in advertising occasionally, removing companies that invested small amounts or invested only in some years of the study period. Given these restrictions, the final sample used for the empirical study consisted of 176 wineries that operated continually from 2004 to 2014, marketing different types of wines. The sampled companies were responsible for $85.24 \%$ of total investment in advertising by Spanish wineries between 2004 and 2014. Regarding the whole population of wineries, the sample 
represents $39.43 \%$ and $61.55 \%$ of total winery sales revenue in 2004 and 2014, respectively.

The dependent variable, advertising investment, was measured in terms of the advertising expenditure of company $j$ in period $t\left(A_{j t}\right)$. The data were drawn from the INFOADEX database, which provides detailed information on advertising expenditure in the Spanish media in the form of print advertising (newspapers, magazines, and supplements), broadcast advertising (TV, cinema, and radio), outdoor advertising, and Internet advertising.

To explain companies' advertising investments, we consider the following variables. First, company reputation $\left(R_{j t-1}\right)$ is proxied by the quality index of the wines produced by the company. As company reputation is assumed to be a function of the firm's past output quality (Landon and Smith, 1997), the company reputation variable is represented by the average of the first lag $\left(Q_{j t-1}\right)$. In addition, using a contemporaneous index of quality might raise the possible endogeneity bias because the quality is also a function of advertising (Tremblay and Tremblay, 2012). The use of a (one-period) lagged quality index overcomes this problem because the index thus becomes an exogenous measure. For every wine produced by winery $j$, the wine quality index is given by Los Mejores Vinos de España Repsol (2004 to 2014), which provides blind tasting quality scores of the best wines in Spain (those that experts assign more than 85 points out of 100). These blind tastings involve the evaluation of factors such as the color, bouquet, flavor, balance, complexity, and aging potential of the wine.

It is generally acknowledged that wine quality depends on subjective sensory assessments and cannot be measured easily or accurately. Thus, as with most experience goods, the quality of a wine is extremely difficult to assess (Oczkowski, 2001). Most wine studies use sensory assessments from wine guides (Benjamin and Podolny, 1999) to measure wine quality and brand reputation. These wine guides rely on the opinions of experts who follow highly systematic procedures and rigorous evaluation standards. However, these blind tastings can cause problems. For example, an assessment might be biased by the tester's personal preferences (Castriota, Curzi, and Delmastro, 2013), so it is not a completely objective quality assessment. Similarly, Cao and Stokes (2010) report that wine experts' ratings may be affected by different sources of personal bias related to a score attribution, discriminating ability, and variability in assigning scores. Finally, authors have noted that wine guides focus on upper-end market segments, so they are not considered fair representations of the whole wine market (Ashton, 2011).

Second, the market share of firm $j$ in its collective brand is given by the expression $M S_{j t}^{c}$. We use a (one-period) lagged market share index to overcome the following problem: using a contemporaneous index of market share might create potential endogeneity bias, as market share is also a function of advertising (Tellis and Fornell, 1988). Given that this index is based on the market share in the last period, it is a predetermined variable for the current period $t$. 
In this paper, control variables related to collective brand characteristics are considered. First, the market growth of the collective brand is a market characteristic that captures the dynamism of the market. It is measured by the percentage growth rate of the total sales of the collective brand between period $t-1$ and period $t$. Second, the market concentration index of the collective brand is proxied by the Herfindahl-Hirschman Index (HHI) and is calculated as the sum of the squared market share $\left(S_{j}\right)$ of all companies in the collective brand in period $t-1$.

Finally, control variables related to the following features of company $j\left(X_{j t}\right)$ are also considered. First, the size of the company is measured by its asset volume. This variable is obtained from the SABI database and is deflated by the GDP deflator index (2004-2014). Second, the age of the company is measured as the difference between the current year and the company's founding year. Third, the number of the firm's products appearing in the wine guide is considered.

Table 1 shows the descriptive statistics and the correlation matrix of the variables used in the study.

\section{Results}

To test the nonlinear relationship between advertising investment and firm reputation, we use regression analysis with panel data. Models 1 and 2 (Table 2) show the estimations of advertising investment as a function of reputation, squared reputation, and control variables. Reputation is not significant in Model 2, but the squared reputation appears to be significant, which suggests a quadratic relationship between reputation and advertising. This nonlinear relationship follows an inverted U-shaped curve with a maximum threshold from which companies reduce their advertising investment.

These results do not lead to the rejection of $\mathrm{H} 1$ and support the idea that the quality reputation of a collective brand member is related to its advertising investment nonlinearly, with a positive slope at low levels of reputation and a negative slope at high levels of reputation. For members with a low reputation, the collective reputation enables low advertising investment. Members with a moderate reputation view higher advertising investment as justified. Finally, companies with a highquality reputation benefit from the collective reputation of a collective brand. The use of both sets of information (firm reputation and collective reputation) by consumers give these companies less motivation to invest in advertising with respect to the investment needed to foster the awareness and trust of consumers with a moderate level of company reputation. This finding reveals the importance of collective brand strategy in the commercialization of experience goods.

Models 3, 4, and 5 (Table 2) also include the effects of company reputation and squared company reputation (which act as independent variables), as well as a moderator variable (company market share within the collective brand) and the 
Table 1

Descriptive Statistics and Correlations

\begin{tabular}{|c|c|c|c|c|c|c|c|c|c|}
\hline Variable & Mean $(S D)$ & $\begin{array}{c}\text { Firm } \\
\text { Advertising } \\
\text { Investment }\end{array}$ & $\begin{array}{c}\text { Firm } \\
\text { Reputation }\end{array}$ & $\begin{array}{l}\text { Market } \\
\text { Share within } \\
\text { Collective } \\
\text { Brand }\end{array}$ & $\begin{array}{c}\text { Collective } \\
\text { Brand } \\
\text { Market } \\
\text { Growth }\end{array}$ & $\begin{array}{c}\text { Collective } \\
\text { Brand Market } \\
\text { Concentration }\end{array}$ & $\begin{array}{l}\text { Firm } \\
\text { Size }\end{array}$ & $\begin{array}{l}\text { Firm } \\
\text { Age }\end{array}$ & $\begin{array}{l}\text { Number of } \\
\text { Products of } \\
\text { the Firm in } \\
\text { the Guide }\end{array}$ \\
\hline $\begin{array}{l}\text { Firm advertising } \\
\text { investment }(\mathrm{t}) \\
\text { (euros) }\end{array}$ & 75339.22 (7968.29) & 1 & & & & & & & \\
\hline $\begin{array}{l}\text { Firm reputation } \\
\qquad(t-1) \text { (index) }\end{array}$ & $17.377(0.189)$ & -.016 & 1 & & & & & & \\
\hline $\begin{array}{l}\text { Market share } \\
\text { within collec- } \\
\text { tive brand } \\
(t-1)(\%)\end{array}$ & $0.061(0.003)$ & -0.002 & $-0.068^{* *}$ & 1 & & & & & \\
\hline $\begin{array}{l}\text { Collective brand } \\
\text { market growth } \\
(\%)\end{array}$ & $0.047(0.0064)$ & -0.201 & 0.008 & $-0.078 * *$ & 1 & & & & \\
\hline $\begin{array}{l}\text { Collective brand } \\
\text { market con- } \\
\text { centration } \\
(t-1) \text { (index) }\end{array}$ & $0.171(0.0040)$ & -0.002 & 0.024 & $0.183^{* * *}$ & $-0.0801 * * *$ & 1 & & & \\
\hline $\begin{array}{l}\text { Firm size (assets, } \\
\text { euros) }\end{array}$ & $34113.48(1809.51)$ & $0.588 * * *$ & $0.009 * * *$ & 0.006 & $-0.043^{* *}$ & $-0.057 * *$ & 1 & & \\
\hline Firm age (years) & $27.296(0.506)$ & $0.183 * * *$ & -0.031 & $0.119 * * *$ & $-0.091 * * *$ & $-0.095 * * *$ & $0.147 * * *$ & 1 & \\
\hline $\begin{array}{l}\text { Number of prod- } \\
\text { ucts of the firm } \\
\text { in the guide } \\
\text { (number) }\end{array}$ & $2.913(0.045)$ & $0.041^{*}$ & $0.231 * * *$ & $0.066^{* *}$ & $-0.075^{* * *}$ & $-0.095 * * *$ & $0.114 * * *$ & $0.111 * * *$ & 1 \\
\hline
\end{tabular}

Notes: For descriptive purposes, all variables are used in their original measurement (they are not centered on the mean, and logarithms are not taken). ${ }^{*} \mathrm{p}<0.10, * * \mathrm{p}<0.05,{ }^{* * *} \mathrm{p}<0.01$. 
Table 2

Relationship between Advertising Investment and Reputation of Collective Brand Members and the Moderating Role of Their Market Share within the Collective Brand

\begin{tabular}{|c|c|c|c|c|c|}
\hline Variable & Model 1 & Model 2 & Model 3 & Model 4 & Model 5 \\
\hline \multicolumn{6}{|l|}{ Independent Variables } \\
\hline \multirow[t]{2}{*}{ Intercept } & $1.891^{* * *}$ & $1.612 * * *$ & $1.623^{* * *}$ & $1.638 * * *$ & $1.589 * * *$ \\
\hline & $(0.329)$ & $(0.361)$ & $(0.361)$ & $(0.361)$ & $(0.359)$ \\
\hline \multirow[t]{2}{*}{ Company reputation $(t-1)$} & $-0.012 * *$ & 0.024 & 0.025 & 0.023 & 0.025 \\
\hline & $(0.006)$ & $(0.019)$ & $(0.019)$ & $(0.019)$ & $(0.019)$ \\
\hline \multirow{2}{*}{ Company reputation $(t-1)$ (squared) } & & $-0.001 * *$ & $-0.001 * *$ & $-0.001 * *$ & $-0.001 * *$ \\
\hline & & $(0.001)$ & $(0.001)$ & $(0.001)$ & $(0.001)$ \\
\hline \multirow{2}{*}{ Company market share within collective brand $(t-1)$} & & & 0.463 & -1.077 & $-4.244 * * *$ \\
\hline & & & $(0.325)$ & $(0.826)$ & $(1.367)$ \\
\hline \multicolumn{6}{|l|}{ Interactions } \\
\hline \multirow[t]{2}{*}{ Company reputation $\times$ Company market share within collective brand } & & & & $0.096^{*}$ & $0.588 * * *$ \\
\hline & & & & $(0.051)$ & $(0.175)$ \\
\hline \multirow[t]{2}{*}{ Company reputation ${ }^{2} \times$ Company market share within collective brand } & & & & & $-0.016^{* * *}$ \\
\hline & & & & & $(0.006)$ \\
\hline \multicolumn{6}{|l|}{ Control Variables } \\
\hline \multirow[t]{2}{*}{ Collective brand market growth } & 0.095 & 0.089 & 0.097 & 0.099 & 0.102 \\
\hline & $(0.171)$ & $(0.170)$ & $(0.169)$ & $(0.169)$ & $(0.168)$ \\
\hline \multirow[t]{2}{*}{ Collective brand market concentration $(t-1)$} & $0.473 * *$ & $0.468 * *$ & $0.405^{*}$ & $0.405^{*}$ & $0.417 *$ \\
\hline & $(0.233)$ & $(0.231)$ & $(0.235)$ & $(0.238)$ & $(0.239)$ \\
\hline \multirow[t]{2}{*}{ Company size (log assets) } & $0.766^{* * *}$ & $0.767 * * *$ & $0.767 * * *$ & $0.767 * * *$ & $0.771 * * *$ \\
\hline & $(0.039)$ & $(0.039)$ & $(0.039)$ & $(0.039)$ & $(0.039)$ \\
\hline \multirow[t]{2}{*}{ Company age } & -0.001 & -0.001 & $-0.002 *$ & -0.001 & $-0.002 *$ \\
\hline & $(0.002)$ & $(0.002)$ & $(0.002)$ & $(0.002)$ & $(0.002)$ \\
\hline \multirow{2}{*}{ Number of products of the firm in the guide } & 0.012 & 0.010 & 0.008 & 0.004 & 0.003 \\
\hline & $(0.023)$ & $(0.024)$ & $(0.024)$ & $(0.024)$ & $(0.024)$ \\
\hline
\end{tabular}


Table 2

Continued

\begin{tabular}{|c|c|c|c|c|c|}
\hline Variable & Model 1 & Model 2 & Model 3 & Model 4 & Model 5 \\
\hline \multicolumn{6}{|l|}{ Adjustment Criteria } \\
\hline Adjusted $\mathrm{R}^{2}$ & 0.252 & 0.253 & 0.253 & 0.254 & 0.2567 \\
\hline Wald $\mathrm{Chi}^{2}$ (comparison to null model) & $480.93^{* * *}$ & $488.58 * * *$ & $488.66^{* * *}$ & $490.94 * * *$ & $500.20 * * *$ \\
\hline$\Delta \mathrm{Chi}^{2}(\mathrm{p}$-value $\mathrm{df} 1)$ & n.a. & $7.65 * * *$ & 0.08 & 2.28 & $9.26^{* * *}$ \\
\hline Estimated maximum (reputation threshold) & n.a. & 12.626 & 12.912 & 12.819 & 12.612 \\
\hline
\end{tabular}

Notes: Panel least squares estimation ( $\mathrm{n}=1,758$ obs. $=176$ firms $\times 11$ years ( 178 lost cases), lagged variable reputation at the beginning of the year). Robust estimation for the standard deviation presented in parentheses. Dependent variable: natural logarithm of deflated advertising investment. ${ }^{*} \mathrm{p}<0.10,{ }^{* *} \mathrm{p}<0.05,{ }^{* * *} \mathrm{p}<0.01$. n.a. $=$ nonapplicable. 
Figure 2

\section{Moderator Effect of Market Share on the Curvilinear Company Reputation-Advertising Investment Relationship: Full Sample versus High Market Share within PDO}

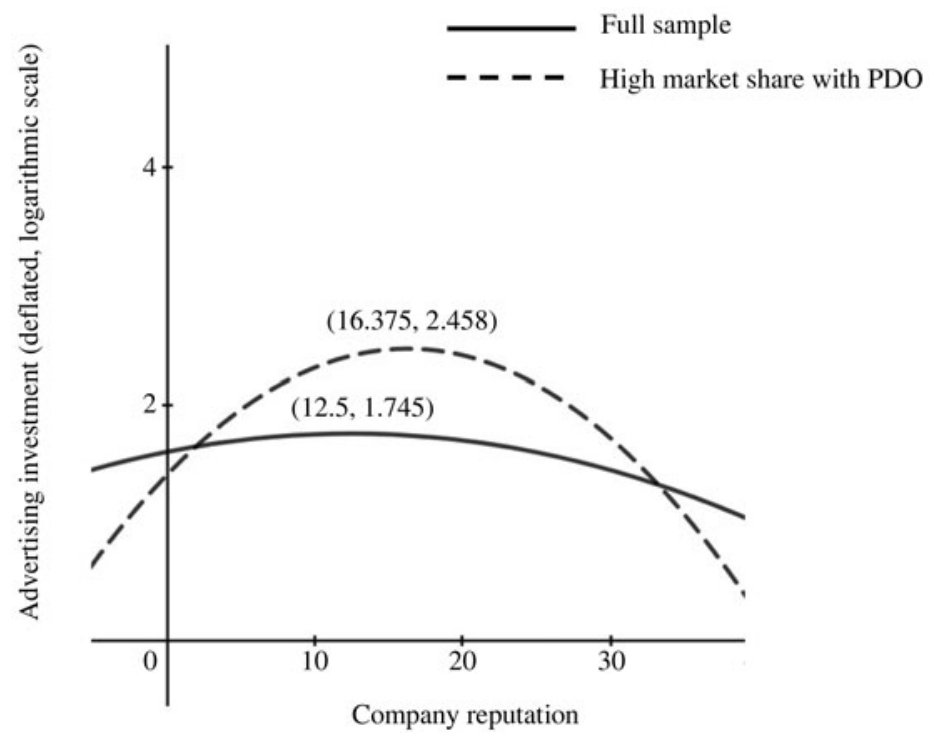

interactions between the independent variable and the moderator. Specifically, Model 5 shows the role of the interaction of market share within a collective brand and squared company reputation in relation to advertising investment. The significant negative coefficient of this interaction term in relation to advertising investment does not lead to the rejection of $\mathrm{H} 2$. This negative sign suggests that the advertising investment of a firm with a high market share decreases as its reputation increases. To better interpret this interaction, the nonlinear relationship between reputation and advertising investment is plotted by distinguishing two groups of firms: the "high market share" companies (those located in the third tercile of bigger companies) and the full sample of companies. Figure 2 shows that the inverted U-shaped relationship between company reputation and advertising investment only holds for companies with a relatively high market share $(\mathrm{n}=$ 594) within their collective brand. Hence, this set of firms would be more likely to increase their advertising investment as their reputation increases (positive slope). However, once a given threshold in reputation is reached, firms would tend to reduce their advertising investment in parallel with the increase of their reputation. For the full sample of firms $(n=1,758)$, the magnitude of the coefficient that links company reputation and advertising investment is smaller than for the group with a high market share. Thus, the nature of the reputation-advertising relationship depends on market share. In short, it seems that members with a low market share in a collective brand have fewer financial resources to develop their individual 
brand, and since they maintain minimum quality standards, they can only benefit from a collective reputation. However, members with a high market share could benefit from both individual and collective reputation, as well as the implicit scale economies of the generic advertising investment of the collective brand.

\section{Conclusions}

This study examines the relationship between reputation and the advertising investment of collective brand members in an experience goods industry, as well as the moderating effect of the company's market share in the collective brand. The central assumptions are that advertising investment has a curvilinear relationship with the quality reputation of collective brand members and that their individual market shares in the collective brand can negatively moderate this relationship. While previous research on this topic has studied the correlation between quality and advertising investment, this study considers company reputation as a proxy of company product quality. In addition, previous studies have not examined the nonlinear relationship between reputation and the advertising investment of collective brand members or the moderating role of market share within collective brands.

The analysis was performed using a panel of 176 Spanish wineries between 2004 and 2014. The results show an inverted U-shaped relationship between reputation and advertising investment of collective brand members. The results also reveal that market share negatively moderates this curvilinear relationship. Thus, the advertising investment of collective brand companies reaches its maximum at intermediate levels of company reputation. In addition, company market share within a collective brand negatively moderates the curvilinear relationship between company reputation and advertising investment in such a way that the advertising investment of a company with a high market share decreases as company reputation increases.

This study has several managerial implications. The choice of a collective brand strategy has major consequences for companies in terms of communication and reputation. The underlying question is whether managers value the effectiveness of collective brands in creating added value for companies. The finding that collective brand companies have lower levels of advertising investment after they reach a quality reputation threshold supports the protection policy of public collective brands in Europe, given that collective brands can affect the advertising investment spillovers of their member companies. Extending the theoretical models of firm reputation (Klein and Leffler, 1981) and collective reputation (Tirole, 1996), the results of this study regarding the inverted U-shaped relationship between reputation and advertising investment suggest that consumers base their quality predictions on the output of an individual company using information about quality in the previous year and information on the quality indicators of the group of companies in the 
collective brand. The value that consumers assign to public collective brands implies that managers of the public institutions that certify the quality of the umbrella brand should provide constant information to the market on the characteristics of their products.

Furthermore, the results suggest that certain characteristics of the company, such as company market share within a collective label, play an important role in the relationship between a company's advertising investment and reputation. Specifically, a collective brand can help its members with a high market share to be more efficient by promoting more efficient investment in advertising by these members. Companies with high levels of reputation that also have a high market share within a collective brand would have a lower advertising investment than companies with a high reputation but a low market share.

This study has some limitations that restrict the generalization of its results. First, this study is based on aggregate data at the company level (reputation and advertising investment), but it does not consider the reputation and advertising investment at the individual product or brand level. Second, we removed companies that invested small amounts of money in advertising or invested only in some years of the study period, and the regression results might have suffered from sample selection bias. In addition, the database only covered a sample of high-quality products (i.e., the best wines from Spain). These restrictions limit the extent to which our results may be generalized to other groups of (lowquality) products. Third, this paper focuses on the effect of reputation and market share on advertising investment. The lack of information restricts the analysis of other factors that might explain the relationship between firm advertising investment and reputation, such as the strength of the collective brand. Finally, the area of study is an experience goods industry, namely the Spanish wine industry. Similar effects should be analyzed in other industries to generalize these results.

As further avenues of research, we encourage scholars to estimate advertising investment at the individual brand level and analyze the influence of the strength of diverse collective brands on the advertising of member companies. Brand strength is one of the most important components of any model of brand equity and can be conceptualized in terms of both consumer attitudes toward the brand with respect to quality and behavioral dimensions such as brand loyalty and brand share (Smith and Park, 1992). It is expected that the strength of the collective brand would influence company advertising investment. In fact, a stronger collective brand should be better at encouraging consumers to try its members' products than a weaker collective brand. Testing these relationships might offer some interesting insight for managers. 


\section{References}

Anderson, K., and Pinilla, V. (2020). Annual Database of Global Wine Markets, 1835 to 2018. Wine Economics Research Centre, University of Adelaide. Available from www.adelaide. edu.au/wine-econ/databases.

Archibald, R. B., Haulman, C. H., and Moody, C. (1983). Quality, price, advertising, and published quality ratings. Journal of Consumer Research, 9(4), 347-356.

Ashton, R. (2011). Improving experts' wine quality judgements: Two heads are better than one. Journal of Wine Economics, 6(2), 160-178.

Bagwell, K. (2007). The economic analysis of advertising. In M. Armstrong and R. Porter (eds.), Handbook of Industrial Organization, Volume 3, 1701-1844. North Holland: Elsevier.

Benavente, D. (2013). The Economics of Geographical Indications. Geneva, Italy: Graduate Institute Publications.

Benjamin, B., and Podolny, J. (1999). Status, quality, and social order in the California wine industry. Administrative Science Quarterly, 44(3), 563-589.

Cao, J., and Stokes, S .L. (2010). Evaluation of wine judge performance through three characteristics: Bias, discrimination, and variation. Journal of Wine Economics, 5(1), 132-142.

Castriota, S., Curzi, D., and Delmastro, M. (2013). Tasters' bias in wine guides' quality evaluations. Applied Economics Letters, 20(12), 1174-1177.

Comanor, W. S., and Wilson, T. A. (1979). The effect of advertising on competition: A survey. Journal of Economic Literature, 17(2), 453-476.

Deluze, A., and Lanotte, H. (2010). Communication collective et réputation dans le secteur française des vins AOC: La particularité du Champagne. $4^{\mathrm{es}}$ Journées de recherché en sciences socials à AgroCampus-Ouest, Rennes.

Dorfman, R., and Steiner, P. (1954). Optimal advertising and optimal quality. American Economic Review, 44(5), 826-836.

Farris, P., and Buzzell, R. (1979). Why advertising and promotion costs vary: Some cross-sectional analyses. Journal of Marketing, 43(4), 112-122.

Fernández-Barcala, M., and González-Díaz, M. (2006). Brand equity in the European fruit and vegetable sector: A transaction cost approach. International Journal of Research in Marketing, 23, 31-44.

Horstmann, I., and Moorthy, S. (2003). Advertising spending and quality for services: The role of capacity. Quantitative Marketing and Economics, 1(3), 337-365.

Klein, B., and Leffler, K. B. (1981). The role of market forces in assuring contractual performance. Journal of Political Economy, 89(4), 615-641.

Landon, S., and Smith, C. E. (1997). The use of quality and reputation indicators by consumers: The case of Bordeaux wine. Journal of Consumer Policy, 20(3), 289-323.

Lee, C. (2002). Advertising, its determinants, and market structure. Review of Industrial Organization, 21(1), 89-101.

Lilien, G. L. (1978). Advisor 2: A Study of Industrial Marketing Budgeting. Cambridge: The Advisor Project.

Loureiro, M. L., and McCluskey, J. J. (2000). Assessing consumer response to protected geographical identification labelling. Agribusiness, 16(3), 309-320.

Marette, S. (2005). The collective-quality promotion in the agri-business sector: An overview. Working paper 05-WP 406, Center for Agricultural and Rural Development, Iowa State University. Available at https://www.card.iastate.edu/products/publications/pdf/05wp406. pdf. 
Marquardt, R., and McGann, A. (1975). Does advertising communicate product quality to consumers: Some evidence from consumer reports. Journal of Advertising, 4(4), 27-31.

Nelson, P. (1974). Advertising as information. Journal of Political Economy, 82(4), 729-754.

Oczkowski, E. (2001). Hedonic wine price functions and measurement error. Economic Record, 77(239), 374-382.

Parker, P. (1995). "Sweet lemons": Illusory quality, self-deceivers, advertising, and price. Journal of Marketing Research, 32(3), 291-307.

Shapiro, C. (1983). Premium for high quality products as returns to reputation. Quarterly Journal of Economics, 98(4), 659-679.

Smith, D. C., and Park, C. W. (1992). The effects of brand extensions on market share and advertising efficiency. Journal of Marketing Research, 29(3), 296-313.

Stigler, G. (1961). The economics of information. Journal of Political Economy, 69(3), 213-225.

Sutton, J. (1991). Sunk Costs and Market Structure. Cambridge, MA: MIT Press.

Tellis, G. J., and Fornell, C. (1988). The relationship between advertising and product quality over the product life cycle: A contingency theory. Journal of Marketing Research, 25(1), 64-71.

Tirole, J. (1996). A theory of collective reputation (with application to corruption and firm quality). Review of Economic Studies, 63(1), 1-22.

Tremblay, V., and Tremblay, C. (2012). New Perspectives on Industrial Organization. New York: Springer.

Wernerfelt, B. (1988). Umbrella branding as a signal of new product quality: An example of signaling by posting a bond. Rand Journal of Economics, 19(3), 458-466.

Willis, M. S., and Rogers, R. T. (1998). Market share dispersion among leading firms as a determinant of advertising intensity. Review of Industrial Organization, 13(5), 495-508. 